\title{
The Application of Flipped Classroom Model in College English Translation Teaching
}

\author{
Hongtian Cen \\ Jiangxi Vocational College of Industry \& Engineering \\ cenht656_0@126.com
}

\section{Keywords: Flipped Classroom; English Translation; Teaching Application}

\begin{abstract}
Under the background of Internet plus, "flipped classroom", as a new education teaching model, has achieved remarkable teaching results in foreign countries. In order to conform to the trend of The Times and improve the teaching quality, "flipped classroom" is also introduced into English translation teaching in China. This paper mainly puts forward the existing problems of English translation teaching in China, analyzes the advantages of "flipped classroom" teaching and the specific application of "flipped classroom" in English translation teaching.

Flipped classroom is a kind of teaching mode that mainly takes students as the subject. Specifically, before the English translation class, students learn the courseware or teaching video by themselves, and students share their harvest and problems in the class. Teachers organize students' individual presentation or group discussion, etc. In class, in order to strengthen students' knowledge grasp and digestion, teachers can answer questions and answer questions for common problems, and improve the teaching effect. In class, in order to strengthen students' knowledge grasp and digestion, teachers can answer questions and answer questions for common problems, and improve the teaching effect.The application of flipped classroom model in college English translation teaching subverts the status of traditional teachers and students in the classroom. Teachers are no longer the ones who assume the teaching subject. Instead, he became a mentor and even a study member.Students, on the other hand, become the subject of learning and act as the organizer of learning, thus increasing the interaction between students and between teachers and students and promoting the communication between teachers and students.
\end{abstract}

\section{Feasibility of flipped Classroom Model in College English Translation Teaching}

\subsection{It is of great practical significance to implement flipped classroom}

The flipped classroom adopts the teaching mode of learning before teaching and utilizes information technology equipment to enable students to learn knowledge independently before class, and to put the application and exploration of course knowledge in class. When students are learning before class, they can repeatedly watch and understand the difficulties in the courseware or teaching video. If they have questions, they can also record them to ask the teacher in class, or ask the teacher on the Internet directly, so that the teacher can prepare lessons in a targeted way. $\mathrm{n}$ addition to answering difficult questions and answering questions, teachers also organize students to participate in interactive activities such as knowledge sharing and group discussion, which increases communication between teachers and students, improves students' participation in class and promotes the improvement of English teaching effect.

flipped classroom is in line with the characteristics of English translation teaching

Because of the strong practicality of English translation courses, students can gradually accumulate translation skills and experience and improve their translation ability only in a large 
number of practices. However, it is difficult to promote the improvement of students' translation ability only by the short teaching time in class. At present, translation teaching mainly teaches specific translation skills and specific translation solutions to specific problems. In terms of teaching methods, it still maintains the linear teaching mode in the traditional classroom, which is completely teacher-centered. After this teaching mode, the comprehensive knowledge of translation majors is often limited, and the practice of translation is usually limited by the accumulation of translation in teaching and the lack of market-oriented translation awareness. After the implementation of flipped classroom, teachers can use classroom time to organize students' English expression and interaction activities, and students can get a lot of translation practice opportunities, thus gradually accumulate translation skills and experience and improve translation ability. Therefore, the flipped classroom teaching model is in line with the characteristics of English translation teaching.

\subsection{The teaching environment can meet the conditions for the implementation of flipped classroom}

With the development and popularization of information technology, most of the classrooms in universities now have wireless network, and there are computer LABS in schools. Internet-connected devices such as smart phones and laptops have been popularized among students. The current teaching environment has basically reached the requirements of implementing flip classroom, at the same time, along with the rapid development of information technology, network English teaching resources will be more rich, students in addition to learning before class the teacher recorded course, can also access English learning website, reading English novels and watch English movies as supplementary material, greatly enrich the teaching content. In addition, with the development of The Times, English translation teaching must be changed to make efforts to accept the intervention of various new knowledge, and the flipped classroom teaching model adds new teaching media and information sources to English translation teaching.

\section{Problems Existing in the Application of Flipped Classroom in College English Translation Teaching}

(1)Challenge your teaching skills and ideas.Compared with traditional classroom teaching, flipped classroom presents technological innovation. Flipped classroom mainly prepares students for preview by watching video. With the gradual development of network technology, many teachers can now find relevant video and video materials on the Internet. However, to ensure the systematic acceptance and mastery of knowledge and improve learning efficiency, teachers should make video that is more suitable for students according to their psychological characteristics and learning conditions. This has a very high requirement for teachers' computer application, so it is a challenge for teachers with ordinary computer skills. $\mathrm{n}$ addition, teachers need to change their own concepts. During the traditional teaching process, teachers accumulate a lot of experience and form fixed teaching forms and habits, and they reject new teaching methods from the bottom of their heart. In addition, the knowledge level of students is different from that of students in the past. Due to the development and popularization of the information age, the knowledge and things students come into contact with are more pioneering. Sometimes the questions raised by students will surprise the teachers.

(2)Challenge the way students learn.The concept of exam-oriented education is deeply rooted in China's education thought. In the 1980s, China began to implement quality-oriented education. However, in the actual teaching, teachers and schools, in order to increase the school's enrollment 
rate, all teaching activities are mainly aimed at exams, so the exam-oriented teaching mode has not been abandoned completely. In this kind of teaching environment, students have been learning passively for many years and lack of learning consciousness and initiative.Therefore, flipped classroom changes students' teaching methods to help students develop good habits of independent learning, which can be quickly integrated into the process of independent learning.

\section{Problems and Countermeasures in the Implementation of Flipped Classroom}

(1)Make English translation teaching plan.In order to improve the teaching quality of "flipped classroom" English translation, teachers should make English teaching plans. The practice of "flipped classroom" in English translation teaching is mainly because of less class time in college English, limited practice time in English translation in class, and the textbooks not only involve one-sided knowledge of English translation, but also lack corresponding English translation exercises after class. In order to improve students' language skills and enable them to master the translation between Chinese and English fluently, teachers should make full use of the new teaching mode of "flipped classroom" and strengthen students' training in English translation. According to the different contents of each chapter, the teacher can make some teaching video to help students prepare for class. The content explained in the class is mainly based on the textbook, which coordinates with the corresponding translation practice questions, strengthens students' chinese-english translation training, cultivates students' interest in learning English, promotes the communication and interaction between teachers and students, improves students' English translation level, and thus helps students improve their English reading and writing ability.

(2) Make English courseware.In "flipped classroom", teachers should learn to use PPT better and make English teaching courseware better. According to the needs of classroom teaching content, teachers can make full use of English online learning resources, insert relevant pictures, animations and video into the teaching courseware, create an active classroom atmosphere, inspire students' enthusiasm for learning English, and cultivate students' interest in learning English translation. At the end of the lesson, the teacher will assign some exercises to consolidate the basic knowledge of students according to their English proficiency.

(3) Strengthen the comprehensive interaction between teachers and students.Traditional classroom teaching mode mainly means that teachers spend a lot of time to explain knowledge, while students passively accept the knowledge taught by teachers. In such a class, teachers and students lack communication and interaction. The teaching concept of "flipped classroom" is "students as the subject, teachers are just the guide". Through "flip" class can make teachers and students in the class, can very good interaction, pull close the distance between students and teachers, help the students in the learning process ownership, better access to knowledge, solve the problem of legacy in the class, help students learn better English translation, enhance the confidence of learning English.

(4) Try to improve the teacher's English teaching. In the "flipped classroom", the teacher needs both rich professional knowledge and education wisdom. Teachers should be good at guiding students to participate in the English classroom, creating a good learning environment for them, encouraging students to give play to the spirit of ownership, and improving students' comprehensive language skills. Meanwhile, teachers should create their own teaching style according to their own specialties. In the process of English classroom teaching, teachers should actively participate in the research work of English classroom, actively declare research topics, strive to improve English teaching methods, improve their English teaching level, and finally actively guide students and help 
them improve their English learning ability.

(5)Cultivate students' learning ability and teach students according to their aptitude. Flipped classroom requires students to develop their English learning ability and then teach them in accordance with their aptitude. English translation teaching is not only the process of imparting knowledge to students, but also the process of spreading culture. The goal of English translation teaching is to cultivate students' comprehensive language application ability, so that students can learn English knowledge efficiently. However, teachers should also properly observe and understand students' specific English learning. Many students are in the initial stage of thinking, they are lively and active, and have a strong curiosity about new things. At this time, the teacher needs to respect each student, select different education methods for each student, teach students in accordance with their aptitude, so as to improve students' English application ability and improve their professional skills.

\section{Conclusion}

The application of flipped classroom model in college English translation teaching subverts the traditional role of teachers and students in the classroom, increases the interaction between students and between teachers and students, and promotes the communication between teachers and students. In this teaching mode, pre-class knowledge teaching can effectively solve the problem of classroom teaching time, which extends the teaching time and enables students to have sufficient thinking time.The cooperative learning mode in class can effectively improve communication and expression ability. It is also conducive to the cultivation of critical thinking; The consolidation and expansion of after-class knowledge can also help students timely digest the classroom teaching content and prepare for the next stage of learning. The application of flipped classroom model in college English translation teaching is a meaningful attempt and exploration. This teaching mode has changed the traditional teaching method of English translation course, flipped the role of teachers and students, promoted the communication between teachers and students, thus giving better play to students' enthusiasm, initiative, creativity and independence in learning, and cultivated students' independent learning ability. In addition, this flipped classroom model also improves the quality and effect of English translation teaching, effectively improves students' practical translation ability and enables students to meet the needs of social work.

\section{References}

[1] Li Fangfang. Problems and strategic analysis of flipped classroom teaching in college English [J]. English square, 2015 (03) : 12-32.

[2] Cui Yanhui, Wang Yi. Flipped classroom and its application in college English teaching [J]. Education.2014 (11) : 23-56. 